\title{
Flux limitations in the ortho pathway of benzoate degradation of Alcaligenes eutrophus: metabolite overflow and induction of the meta pathway at high substrate concentrations
}

\author{
Frédéric Ampe and Nicholas D. Lindley
}

Author for correspondence: Nicholas D. Lindley. Tel: +33 615594 89. Fax: + 3361559673 .
e-mail: lindley@insatlse.insa-tlse.fr

Centre de Bioingénierie Gilbert Durand, Institut National des Sciences Appliquées, URA CNRS 544 \& Laboratoire Associé INRA, Complexe Scientifique de Rangueil, 31077 Toulouse cédex, France

The growth behaviour of Alcaligenes eutrophus using various concentrations of benzoate was investigated. In batch culture, growth was exponential and growth rate $(\mu)$ and yields $(Y)$ were high $\left[\mu=0.51 \mathrm{~h}^{-1}\right.$ and $Y_{\text {xhonzoate }}=0.56 \mathrm{~mol}$ carbon (mol carbon) $)^{-1}$ ] when low concentrations of benzoate $(<5 \mathrm{mM})$ were used. These kinetic parameters were close to the maxima determined in a benzoate-limited chemostat $\left[\mu_{\max }=0.55 \mathrm{~h}^{-1}\right.$ and $Y_{\mathrm{X} \text { benzoate }}=0.57$ mol carbon (mol carbon $)^{-1}$ ] and the part of the energy for maintenance was limited $\left(m_{\text {ATP }}=\right.$

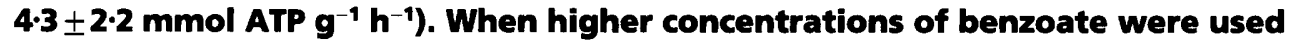
(up to $40 \mathrm{mM}$ ), several metabolic limitations appeared. The specific rate of benzoate consumption was not altered, whereas growth was inhibited [ $K_{\text {i }}($ benzoate) $\approx 27 \mathrm{mM}$ ]. Furthermore, high concentrations of catechol together with some 1,2-dihydro-1,2-dihydroxybenzoate (DHB) transiently accumulated in the medium. The accumulation of catechol was attributed to limiting flux through catechol 1,2-dioxygenase estimated to be $5.2 \mathrm{mmol} \mathrm{g}^{-1} \mathrm{~h}^{-1}$, whereas that of DHB was provoked by an imbalance in the NADH/NAD ${ }^{+}$intracellular content. The direct consequence of DHB accumulation was the induction of the meta pathway for the degradation of catechol, and this pathway contributed up to $20 \%$ of the total flux of catechol to the central metabolism. Finally, when very high concentrations of benzoate were used $(55 \mathrm{mM})$, both growth and the specific rate of benzoate degradation were diminished due to a strong decrease in benzoate 1,2-dioxygenase specific activity.

Keywords: Alcaligenes eutrophus, benzoate, meta-cleavage pathway, ortho-cleavage pathway, regulation

\section{INTRODUCTION}

Alcaligenes eutrophus, a commonly occurring soil bacterium, possesses chromosome-encoded pathways for the degradation of aromatic compounds (Johnson \& Stanier, 1971a). In addition, plasmids extend the range of substrates degraded to pollutants such as 2,4-dichlorophenoxy-acetate (Rasul-Chaudhry \& Chapalmadugu, 1991), chlorobenzenes (Don et al., 1985), methylaromatics

Abbreviations: $\mathrm{B} 120$, benzoate 1,2-dioxygenase; $\mathrm{C} 120$, catechol 1,2dioxygenase; $\mathrm{C23O}$, catechol 2,3-dioxygenase; $\mathrm{DHB}(\mathrm{DH})$, 1,2-dihydro-1,2dihydroxybenzoate (dehydrogenase); $\mathrm{MCl}$, muconate cycloisomerase; $\mathrm{PDH}$, pyruvate dehydrogenase.
(Pieper et al., 1985) or polychlorinated biphenyls (Bedard et al., 1987; Springael et al., 1993).

In $A$. eutropbus, the simple aromatic compound, benzoate, is metabolized via the ortho (also named $\beta$-ketoadipate) pathway (Fig. 1), which has received far less study than the plasmid-encoded meta-cleavage pathways. The highly complex biochemical regulation of the ortho pathway was partly elucidated for $A$. eutrophus strain 335 by Johnson \& Stanier (1971b). Benzoate and cis,cis-muconate appeared to be key intermediates in the induction of the enzymes of the pathway (Johnson \& Stanier, 1971b; Stanier \& Ornston, 1973), but despite those early reports there remain gaps in the knowledge of the regulation, and to date only two genes of the pathway (catD and pcaD 


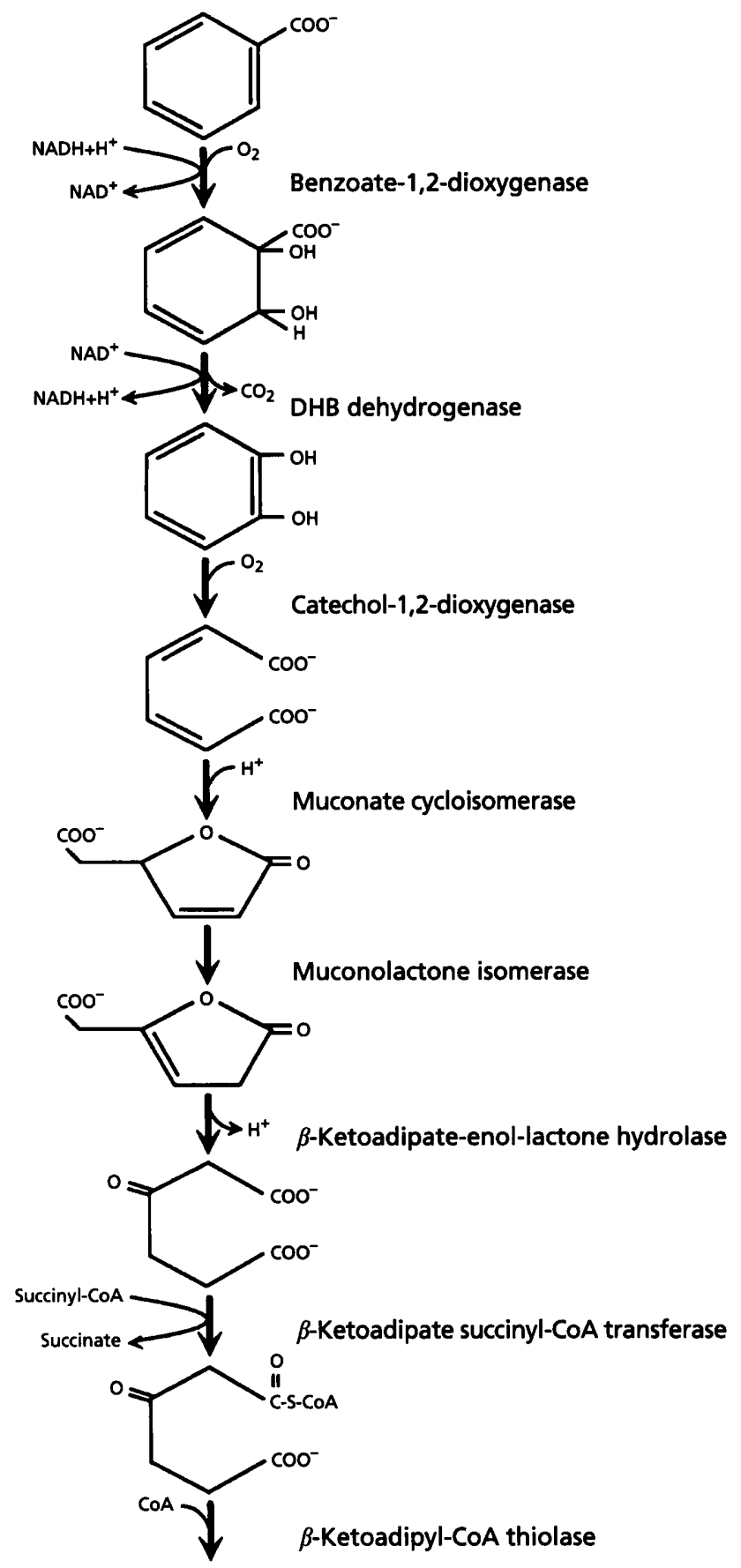

Succinyl-CoA+acetyl-CoA

Fig. 1. The ortho pathway (also named the $\beta$-ketoadipate pathway) for the degradation of benzoate in $A$. eutrophus (adapted from Johnson \& Stanier, 1971a and Reiner \& Hegeman, 1971).

encoding the two lactone hydrolases of $A$. eutrophus) have been cloned and studied (Schlömann et al., 1991).

Despite the rapid degradation of aromatic compounds by A. eutrophus or Pseudomonas sp. observed in the laboratory, biodegradation appears to be far less efficient in natural environments. The presence of other compounds such as organic acids has sometimes been implicated and possible catabolite repression effects have already been examined. However, repression of the ortho pathway by such compounds has not been unambiguously demonstrated and the molecular mechanisms remain obscure (Ornston, 1966; Duetz et al., 1994; Holtel et al., 1994; MacGregor $e t$ al., 1992; Ampe \& Lindley, 1995). Another possible cause for limitation of the catabolism of aromatic compounds by pseudomonads and related organisms would be oxygen limitation, a substrate in the ortbo- and meta-cleavage pathways. This aspect, though not well studied, has already been evoked in the case of benzoate degradation by $A$. eutrophus (Dols et al., 1994; Zhou \& Crawford, 1995). However, most studies reported on the regulation of the catabolism of aromatic compounds have been performed with low or very low concentrations of substrates (generally below $5 \mathrm{mM}$ ) which do not necessarily reflect the stress conditions that bacteria encounter in on-site 'end-of-pipe' waste water treatment where high concentrations might be expected with possible toxic effects.

This paper relates the study of the degradation of benzoate, a model substrate for the ortho pathway, by $A$. eutrophus, with particular emphasis on the effect of substrate concentration. Firstly, a kinetic analysis of the growth of the organism on low concentrations of benzoate was performed. Then, the effects of high concentrations of benzoate on growth and biodegradation abilities, and the response of the cell to this stress were investigated.

\section{METHODS}

Bacterial strains. Alcaligenes eutropbus strain 335 (ATCC 17697) was obtained from LMG (Brussels, Belgium). A. eutropbus strain B9 lacking 1,2-dihydro-1,2-dihydroxybenzoate (DHB) dehydrogenase (DHBDH, Reiner \& Hegeman, 1971) was kindly provided by George Hegeman (Indiana University, Bloomington, USA).

Medium. The mineral salts medium used for growth of A. eutrophus was derived from that described by Johnson \& Stanier (1971a) and contained $\left(1^{-1}\right)$ : nitrilotriacetic acid $(200 \mathrm{mg}), \mathrm{FeSO}_{4} \cdot 7 \mathrm{H}_{2} \mathrm{O}(7 \mathrm{mg}), \mathrm{MgSO}_{4} \cdot 7 \mathrm{H}_{2} \mathrm{O}(580 \mathrm{mg})$, $\mathrm{CaCl}_{2} .2 \mathrm{H}_{2} \mathrm{O}(67 \mathrm{mg}), \mathrm{NaCl}(292 \mathrm{mg}),\left(\mathrm{NH}_{4}\right)_{2} \mathrm{SO}_{4}(2 \mathrm{~g})$, $\mathrm{ZnSO}_{4} .7 \mathrm{H}_{2} \mathrm{O}(10.95 \mathrm{mg}), \mathrm{MnSO}_{4} . \mathrm{H}_{2} \mathrm{O}(1.54 \mathrm{mg}), \mathrm{CuSO}_{4}$ (0.251 mg), $\mathrm{CoCl}_{2} .6 \mathrm{H}_{2} \mathrm{O} \quad(0.2 \mathrm{mg}), \mathrm{H}_{3} \mathrm{BO}_{4} \quad(0.114 \mathrm{mg})$, $\left(\mathrm{NH}_{4}\right)_{6} \mathrm{Mo}_{7} \mathrm{O}_{24} \cdot 4 \mathrm{H}_{2} \mathrm{O}(2 \mathrm{mg})$ and $\mathrm{NiCl}_{2} \cdot 6 \mathrm{H}_{2} \mathrm{O}(0 \cdot 04 \mathrm{mg})$. The $\mathrm{pH}$ of the basal salt medium was adjusted to $7 \cdot 4$ and the medium was autoclaved. A stock solution of $1 \mathrm{M}$ potassium phosphate ( $\mathrm{pH} 7 \cdot 4$ ) was autoclaved separately and added to a final concentration of $40 \mathrm{mM}$. Carbon sources were filter-sterilized and added aseptically to the sterile salts medium.

Cultivation. One litre shake flasks with $150 \mathrm{ml}$ medium were used for preliminary experiments on growth rates and benzoate consumption rates $\left(q_{\text {benzoate }}\right)$. A 1.51 bioreactor from Setric was used for all other experiments. The temperature was maintained at $30^{\circ} \mathrm{C}$, the $\mathrm{pH}$ at $7 \cdot 4$ with controlled addition of $\mathrm{H}_{3} \mathrm{PO}_{4}(1 \mathrm{M})$ and the oxygen partial pressure at $70 \%$ saturation (around $0.15 \mathrm{mM}$ oxygen under these conditions) by agitation and air flow rate variation. The bioreactor was inoculated with $10 \%$ $(\mathrm{v} / \mathrm{v})$ late exponential phase inoculum grown in shake flasks with the same medium. Benzoate was used as sole carbon source for the inoculum. After inoculation, samples were periodically 
withdrawn from the bioreactor with sterile syringes. Batch cultures were performed in triplicate.

For chemostat study, culture conditions were similar to those of batch culture except that the benzoate concentration in the inflowing medium was fixed at $20 \mathrm{mM}$. The dilution rates tested ranged from 0.1 to $0.5 \mathrm{~h}^{-1}$.

Measurement of fermentation parameters. Biomass was measured by cell dry weight determination. A biomass formula of $\mathrm{C}_{4} \mathrm{H}_{6 \cdot 9} \mathrm{~N}_{0.98} \mathrm{O}_{1 \cdot 63}$ (with $5 \%$ ash) determined by elemental analysis was used for calculations. The concentrations of benzoate, DHB, catechol, cis, cis-muconate, acetate and hydroxybutyrate were analysed by HPLC (HP 1050, Hewlett Packard) equipped with an integrator (HP 3396A) and an automatic injector (SP 8775 from Spectra Physic France). Detection was made at $210 \mathrm{~nm}$ with an $\mathrm{HP}$ variable wavelength detector (Hewlett Packard, HP series 1050). The separation was obtained with an AminexR HPX-87H (Bio-Rad) column $(300 \times 7.8 \mathrm{~mm})$ and the operating conditions were as follows: temperature, $65^{\circ} \mathrm{C}$; mobile phase, $\mathrm{H}_{2} \mathrm{SO}_{4}(5 \mathrm{mM}) / \mathrm{CH}_{3} \mathrm{CN}(7 \% \mathrm{v} / \mathrm{v})$; flow rate, $0.8 \mathrm{ml} \mathrm{min}^{-1}$.

Determination of enzyme activities. Benzoate 1,2-dioxygenase (B12O) activity was estimated with whole cells directly sampled from the bioreactor, washed with $100 \mathrm{mM}$ Tris/ $\mathrm{HCl}(\mathrm{pH} \mathrm{7.5)}$ and resuspended in Tris buffer. The cells were placed in a biological oxygen monitor (YSI 5300, Yellow Springs) with $3 \mathrm{ml}$ of the same buffer containing $1 \mathrm{mM}$ benzoate. Blanks without benzoate were prepared for each assay. $\mathrm{B} 12 \mathrm{O}$ activity was expressed as mmol benzoate consumed ( $\mathrm{g}$ cell dry wt) ${ }^{-1} \mathrm{~h}^{-1}$ and takes into consideration that $2 \mathrm{~mol}$ oxygen are consumed per mol benzoate (i.e. oxygen consumption rates are divided by two). This method was adapted from that described by Farr \& Cain (1968). Phenol hydroxylase (phenol 2-monooxygenase, EC 1.14.13.7) was assayed using the same method with phenol $(1 \mathrm{mM})$ replacing benzoate. For all other enzymes, cell-free extracts were prepared. Approximately 50-100 mg (wet wt) of freshly harvested cells were washed twice in $100 \mathrm{mM}$ Tris $/ \mathrm{HCl}$ $\left(\mathrm{pH} \mathrm{7.5)}\right.$ at $4{ }^{\circ} \mathrm{C}$ and resuspended in $10 \mathrm{ml}$ Tris/carballylate buffer (tricarballylic acid, $9 \mathrm{mM}$; Tris $/ \mathrm{HCl}, 35 \mathrm{mM} ; \mathrm{MgCl}_{2}$, $5 \mathrm{mM}$; glycerol, $20 \%, \mathrm{v} / \mathrm{v}$; pH 7.8). The cells were disrupted by sonication and the resulting crude extracts were centrifuged to obtain soluble extracts which were used to assay enzyme actvities. Enzymes of the ortho and meta pathways: DHBDH (Reiner, 1971), catechol 1,2-dioxygenase (C12O, EC 1.13.11.1; Neidle \& Ornston, 1990), cis,cis-muconate lactonizing enzyme or muconate cycloisomerase (MCI, EC 5.5.1.1; Meagher et al., 1990) and catechol 2,3-dioxygenase (C23O, EC 1.13.11.2; Kataeva \& Golovleva, 1990) were assayed by published methods except that the buffer was replaced by $\mathrm{Tris} / \mathrm{HCl}$ $(100 \mathrm{mM}, \mathrm{pH} 7 \cdot 5)$. Blanks without substrate were prepared for each extract. Acetyl-CoA synthetase (acetate-CoA ligase, EC 6.2.1.1) activity was determined by the enzyme assay procedure of Oberlies et al. (1980) in which the formation of AMP from ATP is monitored by coupling the reaction to the oxidation of $\mathrm{NADH}$ via adenylate kinase, pyruvate kinase and lactate dehydrogenase. Blanks without CoA and ATP were prepared for each extract. Isocitrate lyase (EC 4.1.3.1) and malate synthase (EC 4.1.3.2) activities were determined at $\mathrm{pH}$ $7 \cdot 5$ by the procedures described by Maloy et al. (1980). NADH oxidase was estimated using the procedure described by Mandelstam \& Jacoby (1965). Protein was determined by the method of Lowry. Activities are expressed as $\mathrm{nmol} \mathrm{min}^{-1}$ (mg protein $)^{-1}$.

Kinetic measurements. Michaelis constants $\left(K_{\mathrm{m}}\right)$ for catechol with $\mathrm{C} 12 \mathrm{O}$ and $\mathrm{C} 23 \mathrm{O}$ were measured in crude extracts of cells grown in benzoate $(5 \mathrm{mM})$ or phenol $(5 \mathrm{mM})$, respectively, under conditions in which co-induction of both enzymes could be excluded. The $K_{\mathrm{m}}$ for cis,cis-muconate of MCI was measured on crude extracts of cells grown in $5 \mathrm{mM}$ benzoates. Constants were estimated with substrate at concentrations ranging from 0.6 to 10 times the respective values. The $K_{\mathrm{m}}$ values of both catechol dioxygenases for oxygen were estimated with initial oxygen contents ranging from 1 to $100 \%$ saturation with air at $30^{\circ} \mathrm{C}(100 \%$ saturation corresponds to $0 \cdot 22 \mathrm{mM}$ oxygen under these conditions) in the oxygen monitor described above. The kinetic parameters were determined from double reciprocal plots.

Extraction and estimation of intracellular metabolite concentrations. The extraction procedure optimized by Le Bloas et al. (1993) was used. Cell samples of known dry weight were removed directly from the culture, frozen immediately in liquid nitrogen and stored at $-80^{\circ} \mathrm{C}$. To avoid artefacts due to variable amounts of biomass during extraction procedures, the cell sample volume was adjusted (and supplemented with fresh medium) to obtain a final biomass concentration in each sample of $200 \mathrm{mg}$ cell dry wt $\mathrm{l}^{-1}$. While thawing in ice, $100 \mu \mathrm{KOH}$ $(10 \mathrm{M})$ or $200 \mu \mathrm{l}$ concentrated $\mathrm{HCl}$ were added to give a final $\mathrm{pH}$ of 12.5 or 1.2 for alkaline or acid extraction, respectively. In both cases quenching times were less than $0.5 \mathrm{~s}$. The acid extraction procedure was achieved by incubating the $\mathrm{HCl}$ treated sample $(\mathrm{pH} 1.2)$ at $50^{\circ} \mathrm{C}$ for $8 \mathrm{~min}$. before neutralizing with $\mathrm{KOH}(10 \mathrm{M})$ while agitating vigorously. After centrifugation at $12000 \mathrm{~g}$ for $10 \mathrm{~min}$ at $4{ }^{\circ} \mathrm{C}$, the supernatant was used for assays. Acid-labile NADH was extracted by incubating the $\mathrm{KOH}$-treated samples at room temperature for $10 \mathrm{~min}$. After centrifugation at $12000 \mathrm{~g}$ for $10 \mathrm{~min}$ at $4{ }^{\circ} \mathrm{C}$, the supernatant was immediately tested for $\mathrm{NADH}$ without neutralizing to avoid destruction of $\mathrm{NADH}$. NAD ${ }^{+}$and $\mathrm{NADH}$ were assayed using the enzyme procedures described by Le Bloas et al. (1993) by measuring the change of $\mathrm{NADH}$ fluorescence with a spectrofluorometer (Hitachi F2000).

Uncoupling experiments. The possible uncoupling effects of benzoate, DHB, catechol and acetate on respiratory activity were assayed as follows. Cells grown on fructose were sampled during exponential growth phase and placed in the oxygen monitor described above. Oxygen consumption was followed in the presence or absence of the compound tested.

Metabolic fluxes. Metabolic fluxes (carbon and energy) were calculated using the BIONET stoichiometric modelling approach (Vallino \& Stephanopoulos, 1990), based on anabolic precursor (intermediary metabolites and coenzymes) requirements as cited for Escherichia coli (Ingraham et al., 1983). This method assumes that the intermediary metabolite pools remain approximately constant, or at least undergo variations in concentrations which may be considered insignificant in comparison to the flux.

Chemicals. All chemicals were of analytical grade. cis,cisMuconate was synthesized by the procedure of Elvidge $e t$ al. (1950). DHB was prepared using $A$. eutrophus strain B9 by the procedure of Reiner (1971). Purified C12O from $A$. eutropbus $\mathrm{CH} 34$ was a kind gift from G. Sauret-Ignazi (University Joseph Fourier, Grenoble, France). All other substrates, enzymes and coenzymes were obtained from Sigma.

\section{RESULTS AND DISCUSSION}

\section{Growth with non-inhibitory concentrations of benzoate}

When $A$. eutrophus was grown in batch culture in media containing $4 \mathrm{mM}$ benzoate with a further addition of $5 \mathrm{mM}$ to prolong growth, kinetic parameters were 
(a) $5 \mathrm{mM}$ benzoate

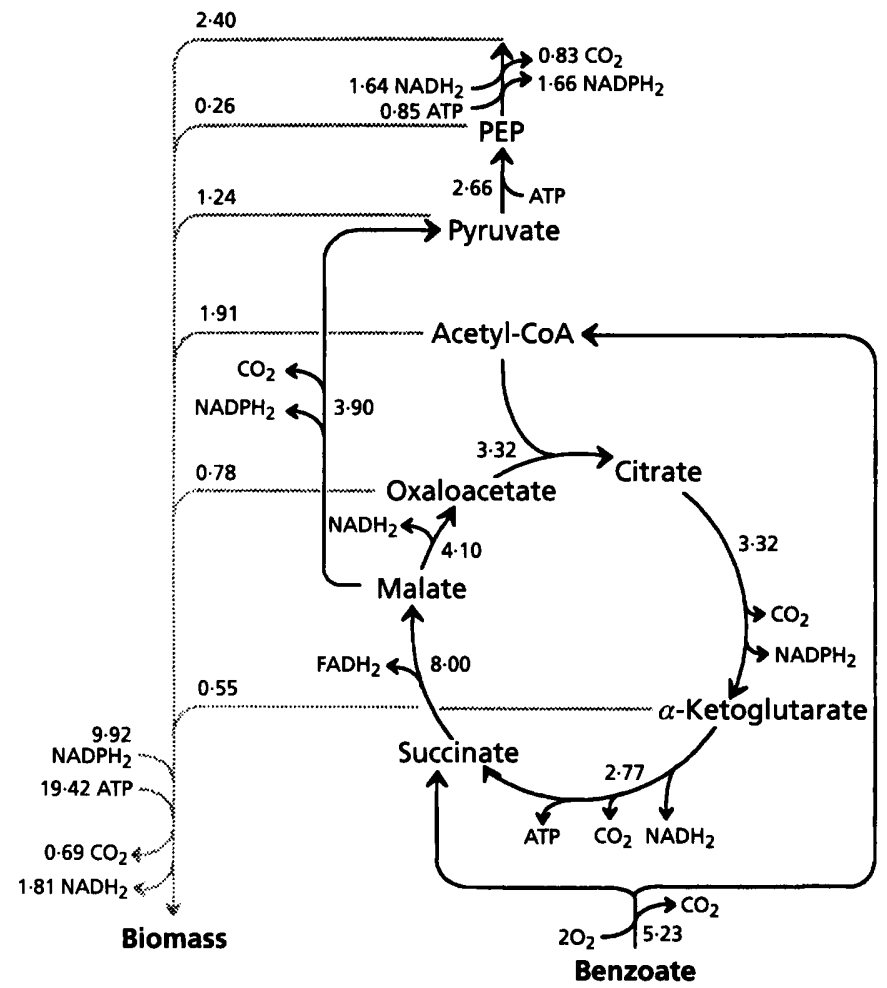

(b) $30 \mathrm{mM}$ benzoate

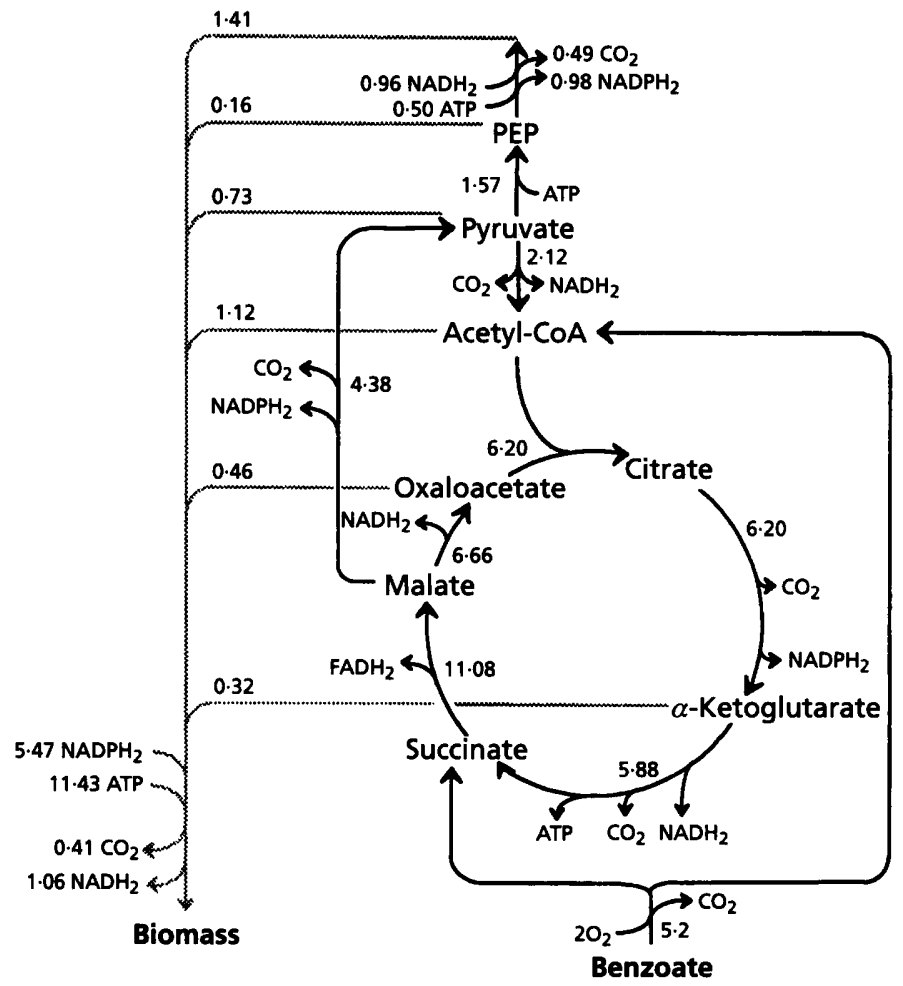

Fig. 2. Flux distribution within the central metabolic pathways based on the kinetic data from exponential growth in batch cultures with (a) low $(<5 \mathrm{mM})$ and (b) high $(30 \mathrm{mM})$ concentrations of benzoate. The flux estimation relating to the culture with $30 \mathrm{mM}$ benzoate used the specific rates measured after $5 \mathrm{~h}$ cultivation (see arrow in Fig. 4), a growth rate of $0.3 \mathrm{~h}^{-1}$ and a specific benzoate consumption rate of $5.2 \mathrm{mmol} \mathrm{g}^{-1} \mathrm{~h}^{-1}$.

constant $\quad\left[\mu=0.51 \pm 0.02 \mathrm{~h}^{-1} ; \quad q_{\text {benzoate }}=5.23 \pm\right.$ $0.1 \mathrm{mmol} \mathrm{g}^{-1} \mathrm{~h}^{-1} ; Y_{\mathrm{X} / \text { benzoate }}=0.56 \pm 0.02 \mathrm{~mol}$ carbon (mol carbon) $)^{-1} ; q_{\mathrm{O}_{2}}=19 \cdot 3 \pm 2 \cdot 1 \mathrm{mmol} \mathrm{g}^{-1} \mathrm{~h}^{-1} ; v_{\mathrm{CO}_{2}}=$ $\left.18.8 \pm 2.8 \mathrm{mmol} \mathrm{g}^{-1} \mathrm{~h}^{-1} ; \mathrm{RQ}=0.97 \pm 0 \cdot 10\right]$ and a true exponential phase was observed. Using the data calculated for $E$. coli for the biosynthesis of building blocks (Ingraham et al., 1983; Holms, 1986) together with the kinetic constants observed during exponential growth on benzoate, carbon flux distribution through the central metabolism and associated energetic yields were estimated (Fig. 2a; Table 1). These estimations assumed that benzoate degradation via the ortho pathway led to equimolar quantities of $\mathrm{CO}_{2}$, succinate and acetyl-CoA being formed. They indicate that little excess (or so-called 'maintenance') energy was produced during this exponential phase, and that the cells had no apparent requirement for pyruvate dehydrogenase (PDH) activity, though the physiological importance of this observation remains obscure. The $\mathrm{PDH}$ of $A$. eutrophus has recently been demonstrated to share a common subunit (dihydrolipoamide dehydrogenase) with other enzymes in the central metabolism (Hein \& Steinbüchel, 1994), and the absence of PDH may allow the cell to use its pool of dihydrolipoamide dehydrogenase for other key reactions.

To confirm the kinetic results seen in batch cultures, chemostat cultures of $A$. eutrophus were established with benzoate as the sole carbon source and limiting substrate.
Table 1. Energy balance based on energy fluxes calculated for batch culture growth on low concentrations ( $<5 \mathrm{mM}$ ) of benzoate as depicted in Fig. 2a

\begin{tabular}{|c|c|c|}
\hline & $\begin{array}{c}\text { Co-enzyme } \\
\text { production- } \\
\text { catabolism } \\
\left(\mathrm{mmol} \mathrm{g}^{-1} \mathrm{~h}^{-1}\right. \\
\mathrm{P} / \mathrm{O}=2)^{*}\end{array}$ & $\begin{array}{c}\text { Co-enzyme } \\
\text { consumption- } \\
\text { anabolism } \\
\left(\mathrm{mmol} \mathrm{g}^{-1} \mathrm{~h}^{-1} \text {; }\right. \\
\mathrm{P} / \mathrm{O}=2)^{*}\end{array}$ \\
\hline $\mathrm{NADH}_{2}$ & $5 \cdot 23$ & $-1.81 \dagger$ \\
\hline $\mathrm{NADPH}_{2}$ & $8 \cdot 88$ & $9 \cdot 29$ \\
\hline $\mathrm{FADH}_{2}$ & $8 \cdot 0$ & 0 \\
\hline ATP & $3 \cdot 4$ & $19 \cdot 42$ \\
\hline Total & 35.49 equiv. ATP & 34.38 equiv. ATP \\
\hline
\end{tabular}

* $\mathrm{P} / \mathrm{O}$, efficiency of energy conservation within the respiratory chain (number of phosphorylation sites per atom oxygen consumed).

$\dagger$ The negative value represents an additional production of $\mathrm{NADH}_{2}$ during the synthetic pathways.

Steady-states at dilution rates $(D)$ ranging from $0 \cdot 1$ to $0.5 \mathrm{~h}^{-1}$ were established and the kinetic behaviour thus obtained was evaluated. Plotting $q_{\text {benzoate }}$ versus $\mu$ gave a straight relationship whose slope gave a theoretical 


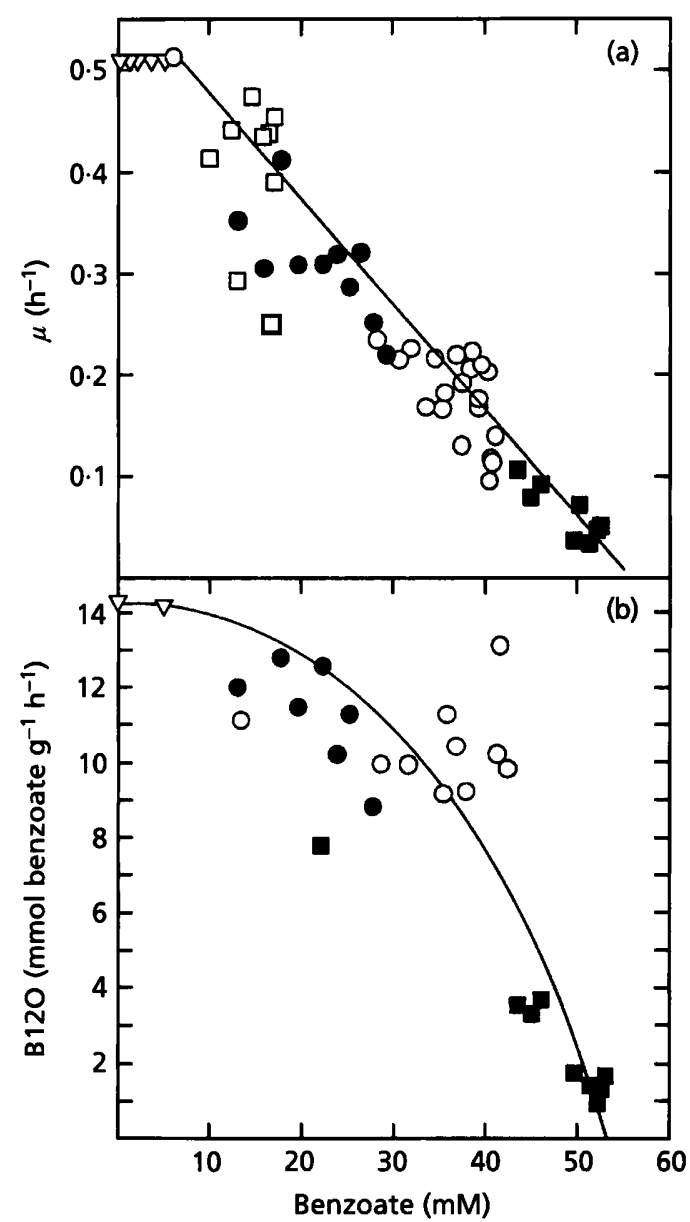

Fig. 3. Specific growth rate (a) and B120 activity (b) as a function of benzoate concentration during batch culture in a bioreactor. Data are instantaneous growth rates collected from the start of cultures with $4(\nabla), 17(\square), 30(0), 40(O)$ and 55 ( $)$ mM benzoate prior to the accumulation of products in the medium.

$Y_{\mathrm{X} / \text { benzoate }}^{\max } 0.57 \pm 0.02 \mathrm{~mol}$ carbon (mol carbon) $)^{-1}$, and when extrapolated to $\mu=0$, enabled a maintenance coefficient of $m=0 \cdot 22 \pm 0.11 \mathrm{mmol}$ benzoate $\mathrm{g}^{-1} \mathrm{~h}^{-1}$ (or $0.027 \pm 0.014 \mathrm{~g} \mathrm{~g}^{-1} \mathrm{~h}^{-1}$ ) to be estimated. Increasing $D$ to $0.6 \mathrm{~h}^{-1}$ provoked the washout of the culture but enabled a $\mu_{\max }$ value of $0.55 \pm 0.02 \mathrm{~h}^{-1}$ to be estimated.

The maintenance coefficient estimated here is of a similar magnitude to that observed for a variety of microorganisms during growth on glucose (Pirt, 1975). It would appear that benzoate is a good carbon and energy source for the growth of A. eutrophus with the capacity to support both rapid growth and high yields of biomass formation.

\section{Inhibition of growth on high concentrations of benzoate}

When batch cultures of $A$. eutrophus were established in which different initial benzoate concentrations $(17,30,40$ and $55 \mathrm{mM}$ ) were used, the specific growth rate diminished as the initial benzoate concentration was increased

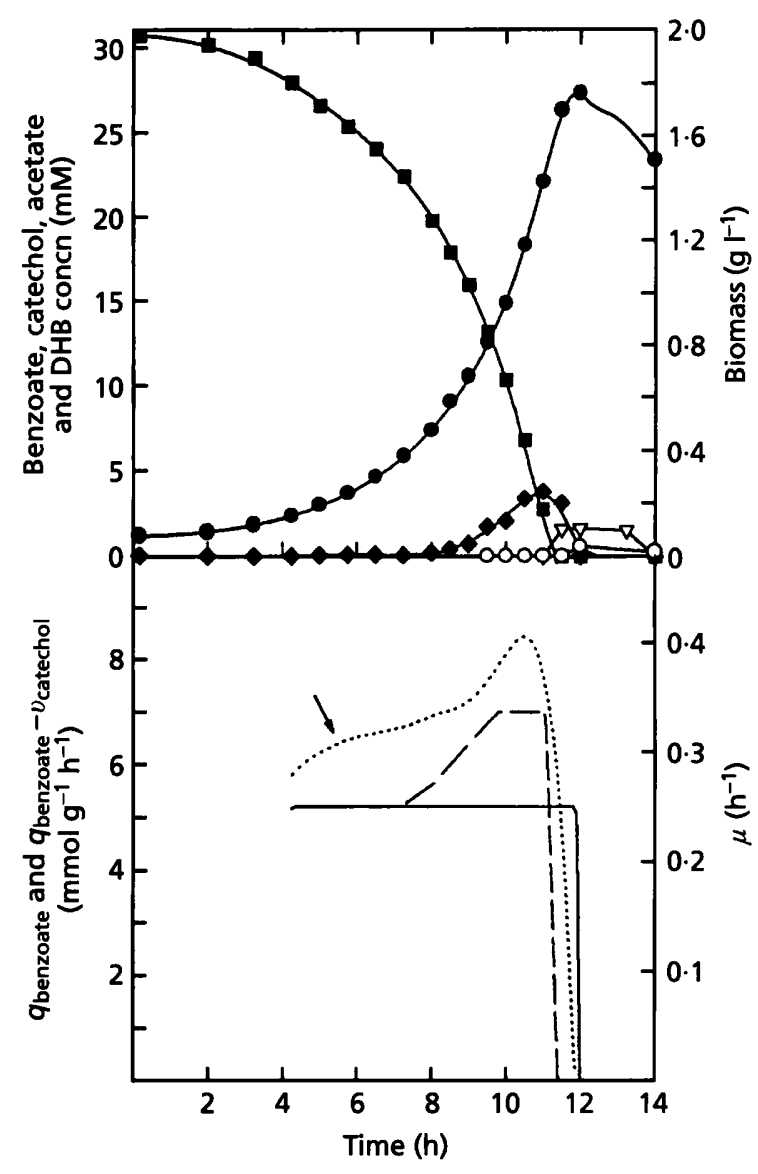

Fig. 4. Kinetics of growth and substrate consumption of $A$. eutrophus in batch culture on $30 \mathrm{mM}$ benzoate. $\square$, benzoate; $\diamond$, catechol; $O$, DHB; $\nabla$, acetate; $\bigcirc$, biomass; dashed line, $q_{\text {benzoate }}$ solid line, $q_{\text {benzoate }}-v_{\text {catechol }} ;$ dotted line, $\mu$. A similar profile was observed for growth on 17 or $40 \mathrm{mM}$ benzoate, except that for $40 \mathrm{mM}$ benzoate, only a little catechol accumulated whereas up to $0.77 \mathrm{mM}$ DHB were found in the medium at the end of the culture period.

(Fig. 3a). No true exponential phase could be observed in these cultures; growth rate increased as benzoate was degraded, i.e as residual benzoate concentration decreased (Figs 4 and 6). The inhibition constant $K_{\mathrm{i}}$ at which $\mu=$ $\mu_{\max } / 2$, was estimated to be $27 \pm 3 \mathrm{mM}$. Such growth behaviour, depicted in Fig. 3(a), is typical of the growth inhibition by a weak acid. This phenomenon has already been described for E. coli, Clostridium thermoaceticum and other bacteria, especially through the inhibition of growth by the production of acetic acid (Wang \& Wang, 1984; Luli \& Strohl, 1990), though benzoic acid has also been reported to inhibit the growth of E. coli (Salmond et al., 1984). These authors attributed the inhibitory effect of weak acids to a decrease in the capacity of the microorganism to maintain $\mathrm{pH}$ homeostasis. The inhibitory effect exerted by benzoate is different from that described for the growth of $P$. putida with phenol (Hill \& Robinson, 1975; Yang \& Humphrey, 1975). This latter compound also inhibits growth, but the kinetics observed fit with Haldane's model (Haldane, 1965). 
Table 2. Effect of benzoate and other compounds involved in the ortho pathway on the specific respiration rate of exponential phase fructose-grown cells of $A$. eutrophus

\begin{tabular}{|lcc|}
\hline $\begin{array}{l}\text { Compound } \\
\text { tested }\end{array}$ & $\begin{array}{c}\text { Concentration } \\
(\mathbf{m M})\end{array}$ & $\begin{array}{c}\text { Respiration } \\
\text { with effector }\end{array}$ \\
\cline { 2 - 3 } & & $\begin{array}{c}\text { Respiration on } \\
\text { fructose alone }\end{array}$ \\
\hline Benzoate & 10 & 0.98 \\
& 25 & 0.92 \\
& 50 & 0.66 \\
Catechol & 100 & 0.47 \\
& 1 & 0.86 \\
& 5 & 0.69 \\
& 10 & 0.38 \\
\hline
\end{tabular}

The uncoupling of the proton-motive force has been postulated to be at the origin of growth inhibition by organic acids (Herrero et al., 1985). Thus, the effect of benzoate and catechol (compounds seen to accumulate under conditions of growth on benzoate) on the respiration rate of fructose-grown cells was assayed. Results showed that neither of the compounds tested provoked an increase in the respiration rate of fructose-grown cells (Table 2). Indeed, both benzoate and catechol led to diminished rates of oxygen consumption while both DHB and acetate at concentrations several times higher than measured in the cultures had no effect on respiratory activity. It would appear that respiratory uncoupling cannot account for the inhibitory effect of benzoate.

\section{Kinetic study of growth with 17-40 mM benzoate}

Growth of $A$. eutrophus in batch cultures with benzoate concentrations of 17,30 and $40 \mathrm{mM}$ gave similar kinetic profiles, and only the culture with $30 \mathrm{mM}$ will be described in detail (Fig. 4). In the first phase of growth, specific rates of benzoate $\left(q_{\text {benzoate }}\right)$ degradation increased progressively to reach $7 \pm 0 \cdot 3 \mathrm{mmol} \mathrm{g}^{-1} \mathrm{~h}^{-1}$. At values of $q_{\text {benzoate }}$ in excess of that observed in batch cultures with non-inhibitory concentrations of benzoate (see Fig. 2a), catechol was seen to accumulate in the medium. Catechol concentration reached $3.7 \mathrm{mM}$ in both cultures with 17 or $30 \mathrm{mM}$ benzoate and was reconsumed in the later phase of the culture. The net flux through the ortho pathway was estimated by the difference between the specific rate of benzoate consumption and that of catechol accumulation (i.e. $\left.q_{\text {benzoate }}-v_{\text {catechol }}\right)$. This value was found to be constant and equal to $5 \cdot 2 \pm 0 \cdot 2 \mathrm{mmol} \mathrm{g}^{-1} \mathrm{~h}^{-1}$ (Fig. 4), i.e. the same as the $q_{\text {benzoate }}$ found for non-inhibitory concentrations of benzoate. As well as the accumulation of catechol, small amounts of DHB were detected in the medium (maximum concentration around $0.6 \mathrm{mM}$ ). During the period of culture in which catechol was reconsumed, acetate accumulated together with trace amounts of hydroxybutyrate in the medium. This co-

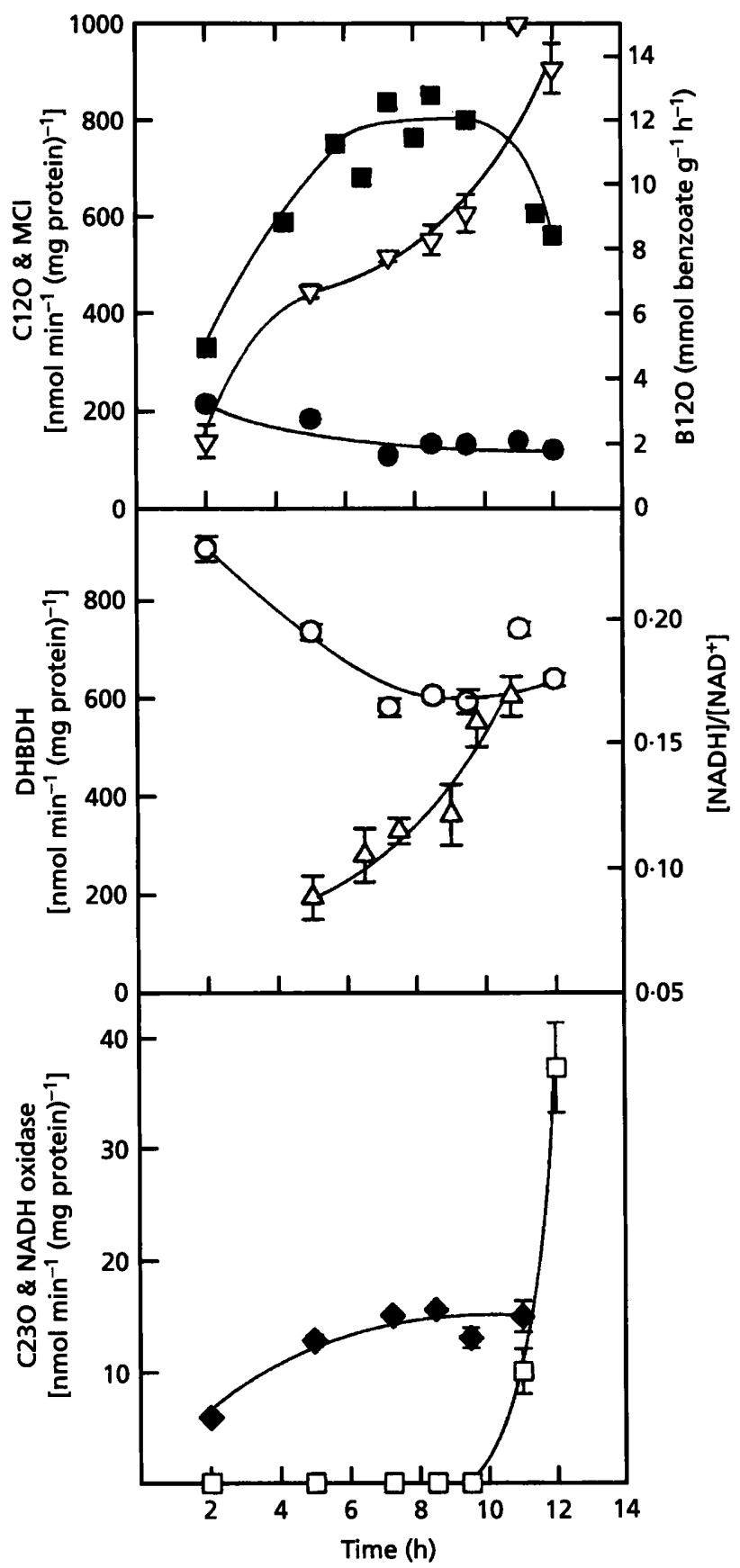

Fig. 5. Specific activity and $N A D H / N A D^{+}$ratio profiles throughout culture with $30 \mathrm{mM}$ benzoate described in Fig. 4 . $\square, \mathrm{B} 120 ; 0, \mathrm{C} 120 ; \nabla, \mathrm{MCl} ; \mathrm{O}, \mathrm{DHBDH} ; \triangle,[\mathrm{NADH}] /\left[\mathrm{NAD}^{+}\right] ; \square$, C230; $-\mathrm{NADH}$ oxidase. Acetyl-CoA synthetase and phenol hydroxylase activities could not be detected at significant levels [i.e. activity measurements were always below $1 \mathrm{mU}$ (mg protein) $)^{-1}$ and $0.04 \mathrm{mmol} \mathrm{g}^{-1} \mathrm{~h}^{-1}$, respectively]. Vertical bars show the SD for the measurements based upon six repetitions for samples taken throughout a single culture. Similar values were obtained for three different batch cultures with $30 \mathrm{mM}$ benzoate.

incided with the appearance of a bright yellow colouration of the supernatant, typical for the accumulation of 2hydroxymuconic semialdehyde. The presence of this product of the meta-cleavage of catechol was confirmed by 
Table 3. Induction of ortho- and meta-cleavage pathway enzymes by intermediates in the degradation of benzoate

Data are the means of four to six determinations \pm SD. ND, not determined.

\begin{tabular}{|lcccc|}
\hline \multirow{2}{*}{ Substrate } & \multicolumn{3}{c|}{ Specific activity $\left[\mathbf{n m o l ~ \mathbf { ~ m i n } ^ { - 1 } ( \mathbf { m g } \text { protein) }} \mathbf{- 1}^{-1}\right]$} \\
\cline { 2 - 5 } & DHBDH & C12O & MCI & C23O \\
\hline Benzoate & $596 \pm 8 \cdot 8$ & $190 \cdot 7 \pm 5 \cdot 4$ & $279 \pm 11 \cdot 6$ & 0 \\
DHB +lactate & $8 \cdot 4 \pm 0 \cdot 2$ & $2 \cdot 3 \pm 0 \cdot 3$ & ND & $20 \cdot 9 \pm 0 \cdot 4$ \\
Catechol & ND & $3 \cdot 03 \pm 0 \cdot 2$ & $48 \cdot 5 \pm 8 \cdot 2$ & 0 \\
cis,cis-Muconate & ND & 0 & $196 \cdot 5$ & 0 \\
$\beta$-Ketoadipate & ND & $21 \cdot 2 \pm 1 \cdot 7$ & ND & 0 \\
Lactate & 0 & 0 & 0 & 0 \\
\hline
\end{tabular}

* Lactate was added as DHB was not used as a growth substrate.

$\dagger$ Added in $0.5 \mathrm{mM}$ increments.

spectroscopic analysis of the supernatant with a peak of absorption at $375 \mathrm{~nm}$.

Carbon and energy fluxes for this culture prior to the period of catechol accumulation were estimated (Fig. 2b). Results with $q_{\text {benzoate }}=5.2 \mathrm{mmol} \mathrm{g}^{-1} \mathrm{~h}^{-1}$ and $\mu=0.3 \mathrm{~h}^{-1}$ showed that maintenance represented $70 \%$ of the total energy (47.3 mmol ATP $\mathrm{g}^{-1} \mathrm{~h}^{-1}$ for a total of $67.5 \mathrm{mmol}$ ATP produced $\left.\mathrm{g}^{-1} \mathrm{~h}^{-1}\right)$ and that a high flux $(2 \cdot 12 \mathrm{mmol}$ $\mathrm{g}^{-1} \mathrm{~h}^{-1}$ ) through PDH was necessary.

\section{Enzymic study of growth with $17-40 \mathrm{mM}$ benzoate}

The first four enzymes of the ortho pathway were assayed throughout the culture with $30 \mathrm{mM}$ benzoate (Fig. 5). Results showed that $\mathrm{B} 12 \mathrm{O}, \mathrm{DHBDH}$ and $\mathrm{C} 12 \mathrm{O}$ specific activities varied during the early hours of growth but remained constant after approximately $6 \mathrm{~h}$ of growth. It is interesting to note that $\mathrm{DHBDH}$ and $\mathrm{C} 12 \mathrm{O}$ activities diminished during this transient period while $\mathrm{B} 12 \mathrm{O}$ activity increased significantly. MCI specific activity showed a tenfold increase which took place throughout the entire duration of the culture. Similar observations were made for cultures with 17 and $40 \mathrm{mM}$ benzoate.

Catechol accumulation. During the early stages of growth, it would appear that $\mathrm{B} 12 \mathrm{O}$ limits benzoate degradation with a good correlation between the increase in $\mathrm{B} 12 \mathrm{O}$ activity and specific rates of benzoate degradation. However, this situation changes radically once $\mathrm{B} 12 \mathrm{O}$ has reached a maximum level. During this phase of the culture, the high $\mathrm{B} 12 \mathrm{O}$ activity $\left(>8 \mathrm{mmol} \mathrm{g}^{-1} \mathrm{~h}^{-1}\right)$ together with the high affinity of this enzyme for its substrates, namely benzoate, oxygen and NADH (respective $K_{\mathrm{m}}$ values $=3 \cdot 9,4 \cdot 3$ and $10 \mu \mathrm{M}$ as measured for the purified enzyme of Pseudomonas arvilla C-1; Yamagushi \& Fujisawa, 1978, 1982) ensured a high rate of conversion of benzoate into DHB. Both DHBDH and $\mathrm{C} 12 \mathrm{O}$ specific activities, which diminished during the first $6 \mathrm{~h}$ of the culture, stabilized thereafter. The specific activity of $\mathrm{C} 12 \mathrm{O}$ was considerably lower than that of $\mathrm{DHBDH}$, though similar to that reported by Johnson \& Stanier (1971a).
The overflow of catechol would appear to indicate a pathway bottleneck localized at the $\mathrm{C} 12 \mathrm{O}$ step. In view of the high affinity of $\mathrm{C} 12 \mathrm{O}$ for catechol $\left(K_{\mathrm{m}}=1.5 \mu \mathrm{M}\right.$ for crude extracts of $A$. eutropbus 335 , this study; $0.3 \mu \mathrm{M}$ for the purified enzyme of $A$. eutrophus $\mathrm{CH} 34$, Sauret-Ignazi et al., 1996), the enzyme was certainly substrate-saturated and hence the low level of expression was most probably the cause of this bottleneck. This hypothesis is further supported by the finding that $\mathrm{C} 12 \mathrm{O}$ activity was not inhibited by the presence of benzoate, DHB or cis,cismuconate. Thus the low activity of $\mathrm{C} 12 \mathrm{O}$ limits the rate of catechol conversion to muconate and hence the overall flux through the ortho pathway under growth at benzoate concentrations in excess of $5 \mathrm{mM}$, but not exceeding approximately $40 \mathrm{mM}$. This enzyme was postulated to be induced by either benzoate or DHB (Johnson \& Stanier, 1971b) though only low levels were induced when grown on lactate in the presence of DHB (Table 3), suggesting that benzoate is the principal inducer. Similarly, neither catechol nor $c i s, c i s$-muconate induced higher expression of $\mathrm{C} 12 \mathrm{O}$ in $A$. eutrophus.

MCl. MCI, the enzyme downstream of $\mathrm{C12O}$ in the ortho pathway, showed a characteristic increase in specific activity throughout the entire culture (Fig. 5). Its affinity for cis,cis-muconate is low $\left(K_{\mathrm{m}}=190 \mu \mathrm{M}\right.$ for crude extracts of $A$. eutrophus 335 , this study; $K_{\mathrm{m}}=55.8 \mu \mathrm{M}$ for the purified enzyme of Pseudomonas B13, Meagher et al., $1990 ; 100 \mu \mathrm{M}$ for that of P. putida, Ornston, 1970). In addition, if the presence of organic acids (benzoate, DHB, but also lactate, acetate, succinate, fumarate, oxaloacetate, citrate, isocitrate, glyoxylate or formate) at concentrations of 1-10 mM had little or no effect on the conversion of muconate into muconolactone, catechol was found to be a strong competitive inhibitor $\left(K_{\mathrm{i}}=43 \mu \mathrm{M}\right)$ of MCI. Since no muconate was detected in the culture supernatant, even when high concentrations of catechol (up to $3.7 \mathrm{mM}$ ) were present, MCI specific activity was not limiting. It remains to be seen if the progressive increase in expression throughout the culture was necessary to maintain flux through the reaction in the presence of catechol. 
DHB accumulation. Cultures for which significant accumulation of catechol was observed also showed DHB accumulation, though later in the fermentation. Since it has been shown that neither benzoate nor catechol influence activity of purified DHBDH (Reiner, 1972) in vitro, the simple enzyme equilibrium effect can be ignored. It was observed that DHB accumulation was often accompanied by trace amounts of hydroxybutyrate in the medium and the presence of polyhydroxybutyrate granules within the cell. These responses in A. eutrophus are generally interpreted as being symptomatic of a requirement for an additional electron sink (Steinbüchel \& Schlegel, 1991). The obvious explanation of limiting oxygen availability for respiration needs to be examined, though $p \mathrm{O}_{2}$ was at all times greater than $70 \%$ of air saturation. When measured, the $\mathrm{NADH} / \mathrm{NAD}^{+}$ratio was seen to increase gradually from an initial value of 0.08 during batch culture to $0 \cdot 2$ (Fig. 5). The impact on DHBDH activity was estimated in vitro with crude extracts of benzoate-grown cells, and the results showed a linear decrease to $50 \%$ activity at an NADH/NAD ${ }^{+}$ratio of 0.5 as compared with $\mathrm{NAD}^{+}$alone. Inhibition of various dehydrogenases of catabolic pathways by a high NADH/ $\mathrm{NAD}^{+}$ratio has been reported before (Snoep et al., 1992; Girbal \& Soucaille, 1994) but not to our knowledge for the enzymes involved in the catabolism of aromatic compounds. Affinities of $\mathrm{B} 12 \mathrm{O}$ for $\mathrm{NADH}$ and of $\mathrm{DHBDH}$ for $\mathrm{NAD}^{+}$have been determined to be 10 and $150 \mu \mathrm{M}$, respectively (Reiner, 1972; Yamagushi \& Fujisawa, 1978). The ratio of these affinities $(0.07)$ is close to the NADH/NAD ${ }^{+}$ratio found at the start of the culture. However, the shift in the NADH/NAD ${ }^{+}$ratio, possibly due to the inhibitory effect of catechol on respiratory activity (see above), would certainly contribute to the diminished in vivo activity of DHBDH. Supportive evidence for this stress condition may be seen in the increase in NADH oxidase activity which provides an alternative oxidation pathway under conditions in which energy excess conditions are encountered (CocaignBousquet \& Lindley, 1995) and thus avoids excess ATP production.

\section{Induction of the catechol meta-cleavage pathway}

The appearance of a yellow colouration of the medium during growth on high concentrations of benzoate has been described (Johnson \& Stanier 1971a). However, no evidence for the induction of the meta-cleavage pathway has yet been reported despite the use of the appearance of a yellow colour (2-hydroxymuconic semialdehyde) as a test for the presence of this pathway. Several substrates and intermediates of the ortho-cleavage pathway were tested for their ability to induce the synthesis of $\mathrm{C} 23 \mathrm{O}$ (Table 2). Catechol did not act as an inducer, contrary to what has been suggested by Johnson \& Stanier (1971a). Indeed, it is logical that catechol cannot act both as an inducer (claimed by Johnson \& Stanier, 1971a) and as a repressor (Hughes \& Bayly, 1983) of C23O synthesis. Only DHB provoked the expression of $\mathrm{C} 23 \mathrm{O}$ synthesis, though it is not clear whether DHB itself is the inducer since spontaneous decomposition of DHB to phenol or salicylate may be occurring. However, no trace of phenol or salicylate could be detected in the supernatant, but this does not exclude the possibility that these compounds were present in the cell. $\mathrm{C} 23 \mathrm{O}$ activity was found only towards the end of the culture period (a maximum specific activity of around $35 \mathrm{nmol} \mathrm{mg} \mathrm{min}^{-1}$ was measured, but was still increasing when the substrate was exhausted; Fig. 5), whereas an extremely low but constant phenol hydroxylase activity was detected in the cells throughout the culture period. It is interesting to note that Hughes \& Bayly (1983) suggested a total repression of phenol hydroxylase by benzoate and catechol, and a $50 \%$ repression of the other enzymes of the meta-cleavage pathway by these compounds. Though our results suggest that the term total is perhaps exaggerated, such a control could explain the lack of induction of phenol hydroxylase by DHB. The accumulation of acetate, a product of the catechol meta-cleavage pathway, confirms that the other enzymes downstream of $\mathrm{C} 23 \mathrm{O}$ in the meta pathway were also induced. The inability of $A$. eutrophus to convert acetate to acetyl-CoA is coherent with the repressed synthesis of acetyl-CoA synthetase observed during rapid growth on benzoate (Ampe \& Lindley, 1995). The absence of acetyl-CoA synthetase activity was also confirmed here. However, the blockage of the pathway at this level provided a fortuitous manner by which flux distribution between the two pathways for the degradation of catechol could be estimated. Approximately $20 \%$ of the accumulated catechol was reconsumed through the meta-cleavage pathway. As both catechol dioxygenases have similar affinities for catechol and oxygen (see Fig. 7), the synthesis of $\mathrm{C} 23 \mathrm{O}$ can be considered as a net increase in the amount of enzyme for the degradation of catechol.

\section{Growth with $55 \mathrm{mM}$ benzoate}

When $A$. eutrophus was grown with $55 \mathrm{mM}$ benzoate, the kinetic profile was different from that observed with 17-40 mM benzoate (Fig. 6). When growth still showed an accelerating pattern, values for the specific rate of benzoate consumption were much lower than those found in the experiments described previously, i.e. constant at approximately $3 \mathrm{mmol} \mathrm{g}^{-1} \mathrm{~h}^{-1}$ during the first $20 \mathrm{~h}$ of growth. The $q_{\text {benzoate }}$ increased thereafter with accumulation of catechol and DHB when specific rates exceeded the value of $5 \cdot 2 \mathrm{mmol} \mathrm{g}^{-1} \mathrm{~h}^{-1}$.

\section{Inactivation of B12O}

$\mathrm{B} 12 \mathrm{O}$ activity was assayed by respirometry on whole cells throughout the various batch cultures as well as in the chemostat described above (Fig. 3b). Results showed that B12O activity was high (i.e. $\geqslant 9 \mathrm{mmol}$ benzoate $\mathrm{g}^{-1}$ cell dry wt $\mathrm{h}^{-1}$, value always greater than the $q_{\text {benzoate }}$ calculated for all the cultures) for benzoate concentrations up to $40 \mathrm{mM}$. Above this concentration, the specific activity fell sharply to $3 \mathrm{mmol}$ benzoate $\mathrm{g}^{-1} \mathrm{~h}^{-1}$ or less, suggesting that the enzyme had been inactivated or its synthesis repressed. Cells grown in the presence of $55 \mathrm{mM}$ benzoate regained high $\mathrm{B} 12 \mathrm{O}$ activity when the concentration of the aromatic compound decreased. The 


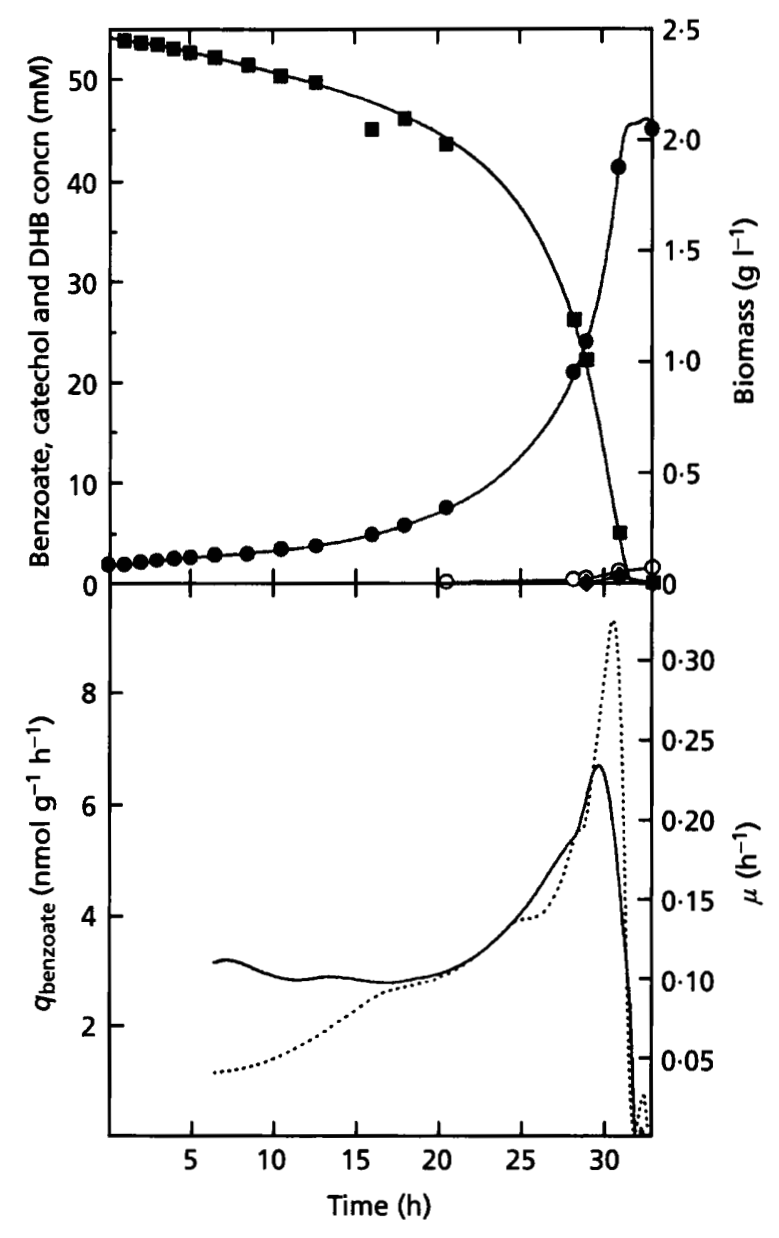

Fig. 6. Kinetics of growth and substrate consumption of $\boldsymbol{A}$. eutrophus in batch culture on $55 \mathrm{mM}$ benzoate. $\square$, benzoate; $\bullet$, catechol; O, DHB; 0 , biomass; solid line, $q_{\text {benzoate; }}$ dotted line, $\mu$.

other enzymes of the ortho pathway assayed did not appear to be affected (results not shown). Therefore, in the presence of high benzoate concentrations (over 40$45 \mathrm{mM}$ ), the conversion of benzoate into DHB by $\mathrm{B} 12 \mathrm{O}$ becomes the limiting step for the degradation of the aromatic compound.

\section{Conclusions}

(1) Benzoate at low concentrations $(<5 \mathrm{mM})$ was a good substrate for the growth of $A$. eutrophus 335, but at higher concentrations up to $40 \mathrm{mM}$, growth was inhibited, but not the degradation of the aromatic compound. It may be possible to exploit this in waste water treatment or depollution strategies in which it is important to have high degradation yields with only minimal biomass production.

(2) The localization of metabolic bottlenecks in the ortho pathway were shown to change in response to the substrate concentration (results are summarized in Fig. 7). At low concentrations (around $5 \mathrm{mM}$ ), a maximum flux was observed through the ortho-cleavage pathway to-

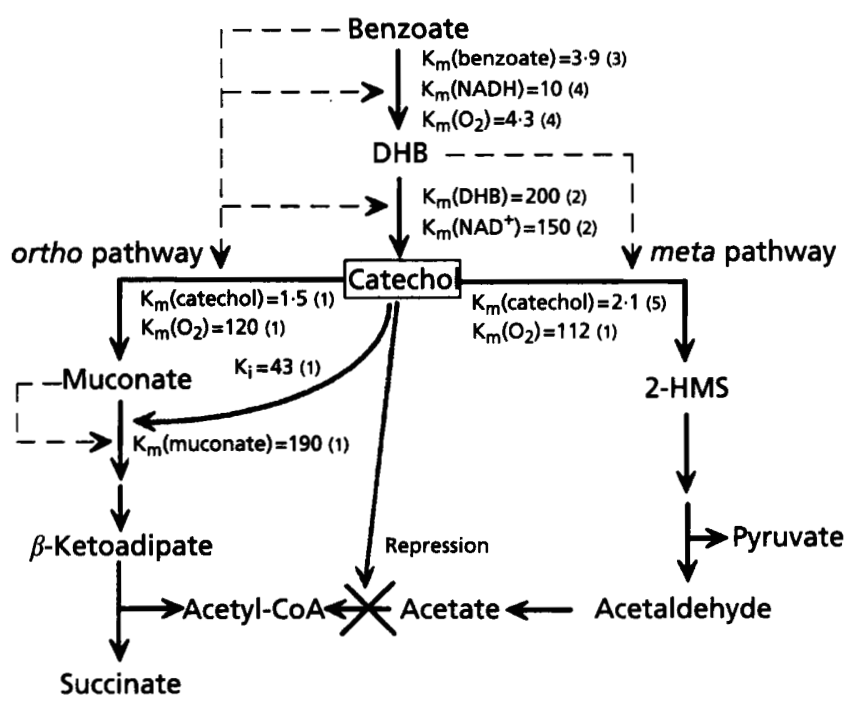

Fig. 7. Summary of the regulation of the first steps of the ortho-cleavage pathway, and kinetic constants of the enzymes involved. Values are for: 1, A. eutrophus 335 and $\mathrm{CH} 34$ (this study); 2, A. eutrophus 335 (Reiner, 1972); 3, P. arvilla C-1 (Yamagushi \& Fujisawa, 1978); 4, P. arvilla C-1 (Yamagushi \& Fujisawa, 1982); 5, P. aeruginosa (Kataeva \& Govlovea, 1990).

gether with high efficiency fueling of an optimized central metabolism with regard to both anabolic precursor metabolites and the necessary co-enzyme requirements (i.e. low maintenance). For higher concentrations of up to approximately $40 \mathrm{mM}$, the bottleneck clearly appeared to be the ortho-cleavage of catechol into cis,cis-muconate catalysed by $\mathrm{C} 12 \mathrm{O}$, and perhaps as a consequence of this phenomenon though to a lesser extent, the conversion of DHB to catechol. Finally, at high concentrations $(55 \mathrm{mM})$, the significantly diminished specific activity of B12O became limiting.

(3) The accumulation of DHB provoked the induction of the other major pathway for the degradation of catechol, the meta-cleavage pathway. We have presented here the first evidence for the role played by DHB in the induction of the meta pathway. Once this pathway had been induced, cells accumulated acetate, the product of the degradation of catechol via this pathway, as would be expected if the repression of acetyl-CoA synthetase activity by catechol (Ampe \& Lindley, 1995) is taken into account.

(4) Pyruvate and the flux through pyruvate in A. eutrophus appear to play an important role in the efficiency of central metabolism. This is supported by the two following observations: (i) growth was very efficient when PDH was not necessary (Fig. 2a); and (ii) the induction of the meta-cleavage pathway on high concentrations of benzoate could also be interpreted as an extra source of pyruvate, one of the direct products of this pathway.

\section{ACKNOWLEDGEMENTS}

We thank M. Tisnes for his help in the synthesis of cis,cismuconate. The authors would also like to thank INRA, CNRS 
and the Midi-Pyrénées regional government for financial support.

\section{REFERENCES}

Ampe, F. \& Lindley, N. D. (1995). Acetate utilization is inhibited by benzoate in Alcaligenes eutropbus: evidence for transcriptional control of the expression of acoE coding for acetyl-CoA synthetase. $J$ Bacteriol 177, 5826-5833.

Bedard, D. L., Harbel, M. L., May, R. J. \& Brennan, M. J. (1987). Evidence for novel mechanisms of polychlorinated biphenyl metabolism by Alcaligenes eutrophus H850. Appl Environ Microbiol 53, 1103-1112.

Cocaign-Bousquet, M. \& Lindley, N. D. (1995). Pyruvate overflow and carbon flux within central metabolic pathways of Cornyebacterium glutamicum during growth on lactate. Enzyme Microb Tecbnol $17,260-267$.

Dols, M., Ampe, F. \& Lindley, N. D. (1994). Effects of oxygen limitations on benzoate degradation by Alcaligenes eutrophus. I $A W Q$ 17th Biennial Conference, July 94, Budapest, Hungary.

Don, R. H., Weightman, A. J., Knackmuss, H.-J. \& Timmis, K. N. (1985). Transposon mutagenesis and cloning analysis of the pathway for the degradation of 2,4-dichlorophenoxyacetic acid and 3-chlorobenzoate in Alcaligenes eutrophus JMP134(pJP4). J Bacteriol 161, 85-90.

Duetz, W. A., Marques, S., de Jong, C., Ramos, J. L. \& van Andel, J. G. (1994). Inducibility of the TOL catabolic pathways in Pseudomonas putida ( $\mathrm{pWW}$ ) growing on succinate in continuous culture: evidence of carbon catabolite repression control. $J$ Bacteriol 176, 2354-2361.

Elvidge, J. A., Lindstead, R. P., Sims, P. \& Orkin, B. A. (1950). The third isomeric (cis-trans) muconic acid. J Chem Soc 2235-2241.

Farr, D. R. \& Cain, R. B. (1968). Catechol oxygenase induction in Pseudomonas aeruginosa. Biocbem J 106, 879-885.

Girbal, L. \& Soucaille, P. (1994). Regulation of Clostridium acetobutylicum metabolism as revealed by mixed-substrate steadystate continuous cultures: role of NADH/NAD ratio and ATP pool. J Bacteriol 176, 6433-6438.

Haldane, J. B. S. (1965). Enzymes. Boston, MA : MIT Press.

Hein, S. \& Steinbuchel, A. (1994). Biochemical and molecular characterization of the Alcaligenes eutropbus pyruvate dehydrogenase complex and identification of a new type of dihydrolipoamide dehydrogenase. J Bacteriol 176, 4394-4408.

Herrero, A. A., Gomez, R. F., Snedecor, B., Tolman, C. J. \& Roberts, M. F. (1985). Growth inhibition of Clostridium thermocellum by carboxylic acids: a mechanism based on uncoupling by weak acids. Appl Microbiol Biotecbnol 22, 53-62.

Hill, G. A. \& Robinson, C. W. (1975). Substrate inhibition kinetics: phenol degradation by Pseudomonas putida. Biotechnol Bioeng 17, 1599-1615.

Holms, W. H. (1986). The central metabolic pathways of Escherichia coli: relationship between flux and control at a branch point, efficiency of conversion to biomass, and excretion of acetate. Curr Top Cell Regul 28, 69-105.

Holtel, A., Marques, S., Möhler, I., Jakubzik, U. \& Timmis, K. N. (1994). Carbon source-dependent inhibition of $x y l$ operon expression of the Pseudomonas putida TOL plasmid. J Bacteriol 176, 1773-1776.

Hughes, E. J. L. \& Bayly, R. C. (1983). Control of the meta-cleavage pathway of Alcaligenes eutrophus. J Bacteriol 154, 1363-1370.

Ingraham, J. L., Maaloe, O. \& Neidhart, F. C. (1983). Growth of the Bacterial Cell. Sunderland, MA: Sinauer Associates Inc.
Johnson, B. F. \& Stanier, R. Y. (1971a). Dissimilation of aromatic compounds by Alcaligenes eutrophus. J Bacteriol 107, 468-475.

Johnson, B. F. \& Stanier, R. Y. (1971b). Regulation of the $\beta$ ketoadipate pathway in Alcaligenes eutrophus. J Bacteriol 107, 476-485.

Kataeva, I. A. \& Golovleva, L. A. (1990). Catechol-2,3-dioxygenase from Pseudomonas aeruginosa 2x. Methods Enzymol 188, 115-121.

Le Bloas, P., Guilbert, N., Loubière, P. \& Lindley, N. D. (1993). Growth inhibition and pyruvate overflow during glucose metabolism of Eubacterium limosum are related to a limited capacity to reassimilate $\mathrm{CO}_{2}$ by the acetyl-CoA pathway. J Gen Microbiol 139, 1861-1868.

Luli, G. W. \& Strohl, W. R. (1984). Comparison of growth, acetate production and acetate inhibition of Escherichia coli strains in batch and fed-batch fermentations. Appl Environ Microbiol 56, 1004-1011.

MacGregor, C. H., Wolff, J. A., Arora, S. K., Hylemon, P. B. \& Phibbs, P. V. (1992). Catabolite repression control in Pseudomonas aeruginosa. In Pseudomonas: Molecular Biology and Biotechnology, pp. 198-206. Edited by E. Galli, S. Silver \& B. Witholt. Washington, DC: American Society for Microbiology.

Maloy, S. R., Bohlander, M. \& Nunn, W. D. (1980). Elevated levels of glyoxylate shunt enzymes in Escherichia coli strains constitutive for fatty acid degradation. $J$ Bacteriol 143, 720-725.

Mandelstam, J. \& Jacoby, G. A. (1965). Induction and multisensitive end-product repression in the enzymatic pathway degrading mandelate in Pseudomonas fuorescens. Biochem J 94, 569-577.

Meagher, R. B., Ngai, K. L. \& Ornston, L. N. (1990). Muconate cycloisomerase. Methods Enzymol 188, 126-130.

Neidle, E. L. \& Ornston, L. N. (1990). Catechol and chlorocatechol 1,2-dioxygenase. Methods Enzymol 188, 122-126.

Oberlies, G., Fuchs, G. \& Thauer, R. K. (1980). Acetate thiokinase and the assimilation of acetate in Methanobacterium thermoautotrophicum. Arch Microbiol 128, 248-252.

Ornston, L. N. (1966). The conversion of catechol and protocatechuate to $\alpha$-ketoadipate by Pseudomonas putida. IV. Regulation. J Biol Chem 241, 3800-3810.

Ornston, L. N. (1970). Conversion of catechol and protocatechuate to $\beta$-ketoadipate (Pseudomonas putida). Methods Enzymol 17A, 529549.

Pieper, D. H., Engesser, K.-H., Don, R. H., Timmis, K. N. \& Knackmuss, H.-J. (1985). Modified ortho-cleavage pathway in Alcaligenes eutrophus JMP134 for the degradation of 4-methylcatechol. FEMS Microbiol Lett 29, 63-67.

Pirt, S. J. (1975). Principles of microbe and cell cultivation. Oxford: Blackwell Scientific Publications.

Rasul-Chaudhry, G. \& Chapalmadugu, S. (1991). Biodegradation of organic halogenated compounds. Microbiol Rev 55, 59-79.

Reiner, A. M. (1971). Metabolism of benzoic acid by bacteria: 3,5cyclohexadiene-1,2-diol-1-carboxylic acid is an intermediate in the formation of catechol. $J$ Bacteriol 108, 89-94.

Reiner, A. M. (1972). Metabolism of aromatic compounds in bacteria. Purification and properties of the catechol-forming enzyme, 3,5-cyclohexadiene-1,2-diol-1-carboxylic acid $\left(\mathrm{NAD}^{+}\right)$oxidoreductase (decarboxylating). J Biol Chem 247, 4960-4965.

Reiner, A. M. \& Hegeman, G. D. (1971). Metabolism of benzoic acid by bacteria. Accumulation of (-)-3,5-cyclohexadiene-1,2-diol1 -carboxylic acid by a mutant strain of Alcaligenes eutrophus. Biochemistry 10, 2530-2536.

Salmond, C. V., Kroll, R. G. \& Booth, I. R. (1984). The effect of food preservatives on $\mathrm{pH}$ homeostasis in Escherichia coli. J Gen Microbiol 130, 2845-2850. 
Sauret-tgnazi, G., Gagnon, J., Béguin, C., Barrelle, M., Markowicz, Y., Pelmont, J. \& Toussaint, A. (1996). Characterisation of a chromosome encoded catechol-1,2-dioxygenase (EC 1.13.11.1) from Alcaligenes eutrophus $\mathrm{CH} 34$. Arch Microbiol (in press).

Schlomann, M., Hartnett, G. B. \& Ornston, L. N. (1991). Use of the Acinetobacter transformation system for the cloning of degradative genes from Alcaligenes eutrophus. p133. In Pseudomonas 1991. Third International Symposium on Pseudomonads. Biology and Biotechnology. Triest, Italy, 16-20 June 1991. Book of Abstracts, p. 133.

Snoep, J. L., Teixeira de Mattos, M. J., Starrenburg, M. J. C. \& Hugenholtz, J. (1992). Isolation, characterization and physiological role of the pyruvate dehydrogenase complex and $\alpha$-acetolactate synthase of Lactococcus lactis subsp. lactis bv. diacetylactis. J Bacteriol 174, 4838-4841.

Springael, D., Kreps, S. \& Mergeay, M. (1993). Identification of a catabolic transposon, Tn4371, carrying biphenyl and 4-chlorobiphenyl degradation genes in Alcaligenes eutropbus A5. J Bacteriol 175, 1674-1681.

Stanier, R. Y. \& Ornston, L. N. (1973). The $\beta$-ketoadipate pathway. Adv Microbiol Pbysiol 9, 89-151.

Steinbüchel, A. \& Schlegel, H. G. (1991). Physiological and molecular genetics of poly $(\beta$-hydroxyalkanoic acid) synthesis in Alcaligenes eutrophus. Mol Microbiol 5, 535-542.
Vallino, J. \& Stephanopoulos, G. (1990). Intracellular flux analysis as means of identifying limiting nodes in amino acid fermentations. In Biotechnology, pp. 1063-1066. Edited by C. Christiansen, L. Munck \& J. Villadsen. Copenhagen: Munksgaard International Publisher.

Wang, G. \& Wang, D. I. C. (1984). Elucidation of growth inhibition and acetic acid production by Clostridium thermoaceticum. Appl Environ Microbiol 47, 294-298.

Yamagushi, M. \& Fujisawa, H. (1978). Characterization of NADHcytochrome $c$ reductase, a component of benzoate 1,2-dioxygenase system from Pseudomonas arvilla C-1. J Biol Chem 253, 8848-8853.

Yamagushi, M. \& Fujisawa, H. (1982). Subunit structure of oxygenase component in benzoate 1,2-dioxygenase system from Pseudomonas arvilla C-1. J Biol Chem 257, 12497-12502.

Yang, R. D. \& Humphrey, A. E. (1975). Dynamic and steady state studies of phenol biodegradation in pure and mixed cultures. Biotechnol Bioeng 17, 1211-1235.

Zhou, E. \& Crawford, R. L. (1995). Effects of oxygen, nitrogen and temperature on gasoline biodegradation in soil. Biodegradation $\mathbf{6}$, 127-140.

Received 8 November 1995; revised 13 February 1996; accepted 5 March 1996. 